\title{
Race and Genetics: Attempts to Define the Relationship
}

\section{Citation}

Fullwiley, Duana. 2007. Race and genetics: Attempts to define the relationship. BioSocieties 2(2): 221-237.

\section{Published Version}

http://dx.doi.org/10.1017/S1745855207005625

\section{Permanent link}

http://nrs.harvard.edu/urn-3:HUL.InstRepos:3008239

\section{Terms of Use}

This article was downloaded from Harvard University's DASH repository, and is made available under the terms and conditions applicable to Other Posted Material, as set forth at http:// nrs.harvard.edu/urn-3:HUL.InstRepos:dash.current.terms-of-use\#LAA

\section{Share Your Story}

The Harvard community has made this article openly available.

Please share how this access benefits you. Submit a story.

\section{Accessibility}




\title{
Race and Genetics: Attempts to Define the Relationship
}

\author{
Duana Fullwiley \\ Department of Society, Human Development, and Health, Harvard School of Public Health, \\ 677 Huntington Avenue, Boston, MA 02115, USA \\ E-mail: dfullwil@hsph.harvard.edu
}

\begin{abstract}
Many researchers working in the field of human genetics in the United States have been caught between two seemingly competing messages with regard to racial categories and genetic difference. As the human genome was mapped in 2000, Francis Collins, the head of the publicly funded project, together with his privately funded rival, announced that humans were 99.9 percent the same at the level of their genome. That same year, the National Institutes of Health $(\mathrm{NIH})$ began a research program on pharmacogenetics that would exploit the .01 percent of human genetic difference, increasingly understood in racial terms, to advance the field of pharmacy. First, this article addresses Collins' summary of what he called the 'vigorous debate' on the relationship between race and genetics in the open-access special issue of Nature Genetics entitled 'Genetics for the Human Race' in 2004. Second, it examines the most vexed (if not always openly stated) issue at stake in the debate: that many geneticists today work with the assumption that human biology differs by race as it is conceived through American census categories. It then presents interviews with researchers in two collaborating US laboratories who collect and organize DNA by American notions of 'race/ethnicity' and assume that US race categories of classification largely traduce human biogenetic difference. It concludes that race is a practical and conceptual tool whose utility and function is often taken for granted rather than rigorously assessed and that 'rational medicine' cannot precede a rational approach to addressing the nature of racial disparities, difference and inequality in health and society more broadly.
\end{abstract}

Keywords genetics, race, rational medicine

All interpretation of meaning, like all scientific observation, strives for clarity and verifiable accuracy of insight and comprehension (Evidenz). The basis for certainty in understanding can be either rational, which can be further subdivided into logical and mathematical, or it can be of an emotionally empathetic or artistically appreciative quality (Weber, 1964/1947: 90).

Duana Fullwiley is an anthropologist of science and medicine concerned with how personal identity, health status and molecular genetics findings increasingly intersect. She has done ethnographic fieldwork in the US, France and Senegal, West Africa on locally varied versions of sickle cell science and medical care. She is also engaged in fieldwork on emergent genetic technologies of race and ancestry testing for pharmaceutical and identity purposes. Fullwiley is currently a Robert Wood Johnson Health and Society Scholar at the Harvard School of Public Health. 
With the creation of the pharmacogenetics research network (PGRN) in 2000, the American National Institutes of Health (NIH) articulated a new goal to 'rationalize' medicine. ${ }^{1}$ Like most accounts of rationalization, the underlying logic of the NIH's new effort was about assuring better practices and securing higher efficiency in drug prescription. The PGRN scientific teams have spent the past six years looking for clues to fit humans' varied, yet specific, genetic profiles to the right pharmaceuticals, and vice versa. The rationale is a move away from what has been called the 'one-size fits all' approach to drug prescription (National Institutes of General Medical Sciences, 2000). With this trend in science, came the idea that a focus upon human genetic difference, which in the US has often translated to racial group distinction, was the right conceptual tool to bring together genetics and pharmacology. This emphasis on exploiting such difference was posited in the very same year that the leaders of both public and private genome mapping teams, Francis Collins and J. Craig Venter, publicly proclaimed that 'we are all 99.9 percent genetically the same regardless of race' (White House, Office of the Press Secretary, 2000).

Four years after Collins' and Venter's White House announcement, a conference was convened at the historically black Howard University (Collins, 2004: S14). In the special supplement of Nature Genetics titled Genetics for the Human Race that published papers from this conference, Francis Collins, as the head of the National Genome Research Institute, revisited certain aspects of the debate: on the one hand, there were scientists who maintained that 'self-identified race or ethnicity is a useful proxy for other correlated nongenetic variables', while, on the other hand, detractors were said to 'argue that race and ethnicity are such flawed concepts that the persistent use of such descriptors prolongs the delay in seeking real causes and lends more scientific validity to the race-health connection than it deserves' (Collins, 2004: S14). He continued: 'After reviewing these arguments and listening to the debate ... one could conclude that both points are correct' (2004: S14). Aware that the debate itself had rekindled the idea that human biology might differ by race, and that the discussion cannot move on until we define what is meant by race and its connection with biology, Collins once more addressed the issue with strategic nuance. After positing that 'ancestral origins', in many cases, 'may have a correlation' to 'self-identified race', however 'imprecise', he added: 'it is not strictly true that race or ethnicity has no biological connection' (2004: S13, emphasis added).

Collins ends his article by setting out seven key points to indicate 'what additional research is needed' (2004: S14), ranging from the need to move beyond 'weak surrogate relationships ... to get to the root causes of health and disease' to a call for more research into environmental factors, followed by a caveat that if only genetic factors are considered, [then] only genetic factors will be discovered', to calls for 'more anthropological, sociological and psychological research into how individuals and cultures

1 The term 'rational medicine' is often used to describe pharmacogenetics. For more on this idea and the 'dictate' that race be used to guide this thinking, see Evans and Relling, where, in one of the first reviews on the issue, they write:

... all pharmacogenetic polymorphisms studied to date differ in frequency among ethnic and racial groups. ... The marked racial and ethnic diversity in the frequency of functional polymorphisms in drug- and xenobioticmetabolizing enzymes dictates that race be considered in studies aimed at discovering whether specific genotypes or phenotypes are associated with disease risk or drug toxicity (1999: 488). 
conceive and internalize concepts of race and ethnicity' (2004: S14). In a separate entry from that specifying attention to 'culture', he also added that: 'we must assess how the scientific community uses the concepts of race and ethnicity and attempt to remedy situations in which the use of such concepts is misleading or counterproductive' (2004: S15). In this article I present some such uses. Through ethnographic observation, with affinities to that of 'scientific observation' described by Max Weber in the opening epigraph, I provide excerpts of rationales from scientists on their uses of race, its 'clarity' and 'accuracy', as it functions as a 'practical operator' in their daily research lives (Bourdieu, 1977: 97).

One year before the Howard conference, in 2003, I began conducting fieldwork in two collaborating laboratories where researchers were focused on the intersection of pharmacogenetics and race. (They were among the first cohort granted NIH funding in the first cycle of PRGN awards.) During my research, it became clear that the ambition to produce rational medicine or 'individualized medicine' often led scientists to extrapolate from the 'individual' DNA differences they witnessed in the lab to the general categories of racial grouping used in the US, with all of their complexities. In doing so, many came to believe not simply that race should be used as 'a useful proxy for other nongenetic variables', but also that human biology differed by race in a more or less consistent way. Beyond the labs where I worked, one finds evidence of what I have called the 'molecularization of race' (Fullwiley, 2007) in and alongside efforts to specifically address 'minority health' and in broader moves to research genetic variation between groups in the form of PGRN supplementary grants to collect 'diverse' (non-white) DNA. ${ }^{2}$ Empirically, scientists' belief that biology differs by race becomes clear in their daily practice of collecting and sorting human DNA, as well as in their discovery and analysis of oftentimes very infrequent (i.e. individual, rather than group) findings in human genetic variation as these may bear on pharmaceutical susceptibility.

In the space permitted here, I concentrate my efforts on understanding how, despite the rigorous naming and interpreting of genetic data through the prism of race, as well as a belief on the part of many pharmacogenetics practitioners that human biology corresponds to US census categories (see Fullwiley, 2007: 13-17), the concept of race itself eludes various of my key informants working in this field. ${ }^{3}$ How, I ask, does this happen?

The answers are not simple. New reports regularly carry stories of findings from association studies indicating that US populations divided along common socially accepted racial lines are afflicted by differing rates of disease and death. The conclusion drawn by many scientists and lay readers is that race must be biological. Many of those both in the life and in the social sciences feel that further investigation is required into the environmental factors that may impress upon genetic expression. These researchers suspect that genes often get associated with 'outcomes' which are in fact the biological and bodily consequences of living one's life as a racialized subject in North America (Braun, 2002; Cooper et al.,

2 See the goals and recent grants of the 'Ethics and Communities' arm of the program at http://www.nigms.nih.gov/ pharmacogenetics/prnsupp_abstracts.html

3 American census category definitions of race are often used in genetics studies in spite of thoughtful editorials that detail the pitfalls of this practice (see Nature Genetics, 2000). 
2003; Foster and Sharp, 2002; Lee et al., 2001; Ossario and Duster, 2005: 116). Despite the complexities, many others feel justified in analyzing DNA taken from peoples who identify, or are identified, as belonging to a particular racial group for the purposes of scientific studies (Burchard et al., 2003; Risch et al., 2002). The dual message from some of America's leading genome researchers-that race matters in genetics, and that we should move beyond race as a surrogate-leaves most of the scientists with whom I conducted fieldwork confused about what they are finding, how it should be interpreted and to whom. In this article I suggest that scientists often get stuck between two, if not more, discourses, as they are convinced by the many studies that tease out racial difference, yet they know, intellectually, that there are myriad problems to racial generalizations derived from findings such as their own. I have mostly worked with researchers who deal with very rare mutations that may or may not be unevenly distributed between the US racialized groups that these researchers have decided to study through convenience and geographical availability (due to the fact that recruited subjects live in the San Franscisco Bay area, where these labs are located, in large numbers).

\section{Daily dynamics}

In what follows, I draw on interviews with two teams of pharmacogenetic scientists at the end of a six-month fieldwork stay in two labs when trust and, in many instances, degrees of friendship had been established. The reader may wonder about ethnographic power dynamics when such charged issues are at stake, about racial tensions or affinities shared between the anthropologist of race-use in science and her race-using 'subjects'. Many of my interlocutors self-identified as 'bi-racial', and understood me to be 'bi-racial', while they were also oftentimes 'bi-cultural'. Several who self-identified as 'white/Caucasian' were involved in 'bi-racial' relationships and, during my fieldwork, one such self-identifier had his first child, who was bi-racial. Yet, they possessed very recently 'mixed heritage', unlike my own, which is African-American and English-Irish-American within a family that has been in the US for at least five generations (according to my Mormon relatives). Most researchers with bi-racial and/or bi-cultural experiences had one parent who had arrived as a first-generation immigrant, or had themselves recently come to the US. Such was the case for several scientists from Asia, South Asia and Europe. Four of the world's continents were represented by scientists in the two labs. As we will see below, the principal lab discussed here was interested in comparing four US racial/ethnic groups that they termed 'African-Americans', 'Chinese-Americans', 'Caucasian-Americans' and 'Mexican-Americans'. With the exception of African-American, each of these groups had 'scientific representation' on the two teams, or scientists who self-identified, at least in part, with the 'origins' rooted in these hyphenated terms. Several African-American temporary recruiters, or students visiting through mentorship programs, did pass through for short stays periodically. No Africans were ever affiliated with the labs.

Many of the researchers at these two sites were of roughly my age at the time (late 20s early 30s), although some were considerably older. In the practice of participant observation, I occupied a position known to my informants as 'shadowing', a process whereby they would inform me of scientific issues and help me to understand their projects and various technologies. They were also free to ask me questions, and often posed queries regarding whether or 
not I thought that I might want to become a scientist, or simply stated that I 'should'. My presence as ethnographer and observer did not affect all in the same way: one researcher was nervous and wondered if they were being 'audited'. Others swore me to secrecy about their papers in progress, worried that I might accidentally lead to them being 'scooped' (I indeed promised them confidentiality, as I worked with other labs). Yet most entered into conversations, daily work and relationships with me with relative ease. People understood that they were free to talk with me as they liked, or not. The majority chose to let me shadow them from time to time, graciously answered my various queries, and seemed to enjoy sharing aspects of their work that were either frustrating, exciting, or both. One graduate student confided that no one outside of the lab had ever let him finish his project description in a casual conversation-not even his dad, and thus was 'happy to talk'. One lead researcher who quickly informed me that most of the variation they were finding was 'African- American', and that thus 'clearly race was important for genetics', asked that I 'learn and engage with some of their science'. Another informed me that a key African-American sociologist had criticized him publicly, and that he simply hoped that 'we could each keep an open mind' about what he called 'the reality of race'. He gladly invited me to study his own lab separately, which resulted in an extended stay with his group as well.

After months of witnessing the selection of human subjects, the collection of DNA samples, the organization of those samples by race (in spaces ranging from the virtual organization of computerized databases to the placement and storage of DNA in sub-20 or 80 degree freezers), I eventually asked each scientist about their sorting technique of racial binning. The latter was self-evident for many, and unquestioned by most. Because the centrality of race was obvious - a visible yet invisible technology that infused all stages of the research-I came to wonder, and finally asked my interlocutors: 'How do you define race?' Like Collins, I had assumed a certain 'clarity'. In so doing, I committed an error, for practical categories are not always obvious and the 'essential characteristic of practice' may be 'precisely the fact that excludes such questions' (Bourdieu, 1977: 106). Most of my informants drew a blank at the question, leading to a pause in the interview that lasted anywhere from 5 to 30 seconds before they then offered responses that were often unsure. ${ }^{4}$ The pause was, in some cases, the product of a desire to be cautious around such a contentious issue. Yet for the most part, it was simply due to confusion about what race is. When probed about its relationship to genetics, and to their projects in particular, their usual intellectual rigor was replaced with nervous laughter and, in some cases, embarrassment. As one exclaimed, they simply 'did not understand what race is!'

\section{Race and nominalism}

Race is a thing of our world like no other. Americans in general often use the word without much reflection. It might indeed occupy a tiny portion of what philosopher Martin Heidegger amorphously termed 'the background', that which just is and does not warrant our reflection until its unity 'breaks down'. Even when the breakdown of race occurs in many areas of American social life, it is often reconstructed and made 'whole' again. One recent

4 All interviews were conducted on a Sony digital minidisk recording device. The timing of these pauses is based on the digital timing mechanism inscribed in each recording. 
example of this was in the 2000 US census race classification that allowed respondents to report themselves as 'mixed race'. Many African-Americans with mixed ancestry did not choose this option, but simply marked the category that best represented descriptions that they had been raised to understand themselves 'to be' in North America-that is 'monoracially' black (Lee and Bean, 2004: 233). The decision to mark oneself or not mark oneself as mixed-race differed according to where respondents lived-notably between those who lived in the deep South and those who lived in the ten states where 64 percent of all multiracial identification took place (New York and California among them, as well as Hawaii). In general, those in cosmopolitan centers, with high rates of immigration, diversity, and more demonstrated tolerance of others, were more likely to report racial mixing (Lee and Bean, 2004: 235). Perhaps more telling, when Americans acted on the liberty of marking more than one category, the National Center for Health Statistics created a formula that, in effect, 'reallocated' the multiracial population back into a single race group (Wellner, 2003: 2). This move, and the technology permitting it, was presented as an aid to market researchers who were vexed by the 2000 census data, which complicated their traditional formulas of 'niche' advertising to racial groups (Wellner, 2003: 2).

There is a long debate in philosophy between 'realists' who argue that the mind names entities that correspond to likenesses 'out there' in the world, and 'nominalists' who, at their most extreme, argue that all names, categories and taxonomies are imposed on the world by the human senses. Mediating between these positions, Ian Hacking has proposed the concept of 'dynamic nominalism', suggesting that 'our practices of naming interact with the things that we name' (2002: 6). As sociologist Troy Duster has put it: 'when race is used as a stratifying practice (which can be apprehended empirically and systematically) there is often a reciprocal interplay of biological outcomes that makes it impossible to completely disentangle the biological from the social' (2001: 221). Both Hacking and Duster are concerned with the interchange 'between what there is (and what comes into being) and our conceptions of it' (Hacking, 2002: 6). Race in many respects demands an analysis that pries open this 'looping effect of human kinds' (Hacking, 1995) through beliefs about the self, others and 'the human' more generally. To get to some of these issues, I query scientists' views about the purity of race and their use of it to define human variation even as competing discourses about its validity for genetics simultaneously circulate in the larger cultural field.

In the principal pharmacogenetics laboratory I draw upon here, one arc of this looping effect was a tracking of human difference through documenting frequency differences in the distribution of Single Nucleotide Polymorphisms, or SNPs, between groups distinguished by common racial categories in the United States. This happened without much reflection, in part because the lines of race were seen to be there; and, through their very social reality, they subsumed the imprints of human population history (periods of isolation, migration and mixing), geography, and, in some respects, the very bounds of these scientists' own vision. Percentages are a crucial conceptual tool for pharmacogenetics: the threshold for defining something as a SNP is that it must occur in 1 percent of the sampled populationthat is to say, it must not be simply a variation in a single or few rare individuals. Yet, in certain cases, frequencies of less than 1 percent were used in discussions about how best to define human difference as it relates to pharmacogenetics. Nucleotide changes found once (on one chromosome in one person in a defined study) are said to be 'singletons', those found twice 'doubletons' and those three times, 'tripletons', etc. Such exceedingly rare 
findings, far below the consensus prevalence threshold for SNPs, also had a linguistic and conceptual place in the lab that often served to reify the biogenetic basis of human difference. This was, however, not solely a matter of giving salience to human particularism. These rare findings, as will be seen in one of the interviews to follow, came to be conceived of as important for research because they had the potential to further scientific knowledge on drug uptake mechanisms, and could thus benefit humanity as a whole. One of the long-standing ironies of humanist discourse has been that an orientation to human particulars is justified by an appeal to universal benefit. For the science at hand, the key point is that 'individuals' come to stand in for 'populations'. And yet, of course, conceptually and practically, individuals are not populations.

\section{The labs}

In early March 2003, I began a six-month fieldwork stay at the University of California, San Francisco's (UCSF) Department of Biopharmaceutical Sciences whose chair, Kathleen Giacomini, has a four-year grant as part of the PGRN to conduct a study on the Pharmacogenetics of cell Membrane Transporters (or PMT). ${ }^{5}$ Cell membrane transporters are vital to understanding the first and last phases of drug distribution, since these are proteins that sit on the outside or inside of cells that determine what chemical substance gets taken up, and in what quantities (influx), and what gets expelled when necessary (efflux). Any drug to which we are exposed-toxin or medication-must interact with transporters before it can be metabolized by enzymes (which have been the focus of pharmacogenetics since the 1950s). The PMT project is ambitious, with over 52 transporters and their genetic variants being characterized, tested in cell systems and, finally, investigators hope, challenged by their drug substrates in animals or humans.

Giacomini worked with another local researcher, Esteban González Burchard, to help her collect a panel of 'ethnically and racially' diverse DNA donors for clinical trials. This cohort was called SOPHIE and it consisted of 'African-Americans', 'Caucasian-Americans', 'Mexican-Americans' and 'Chinese-Americans' who would consent to be called back for in vivo drug trials and who lived locally in northern California. Members from the Burchard lab were responsible for recruitment. The point of recruiting individuals to participate in SOPHIE was to overcome what PMT researchers saw as limitations in the National Institutes of General Medical Sciences' ethnically diverse DNA panels. These are the 'Polymorphism Discovery Resource Panel' (PDR) and the Coriell Institute's 'Human Variation' panels, which my informants simply referred to as 'Coriell'.

Researchers involved in PMT are pioneers of their fields. No one has done more extensive work on cell membrane transporters than Kathleen Giacomini. Her achievements have been recognized by the International Pharmaceutical Federation (FIP) Pharmaceutical Scientist of the Year award in 1999 and election to the American Association for the Advancement of Science in 2001. Others at the helm of the project have received prestigious accolades, such as membership at the Institute of Medicine, the National Academy of

5 Due to either their high profiles, or to the extreme specificity of their research, scientists' real names are used throughout (when they are named). Consent to do so was obtained by the author and approved through New York University's IRB option for attribution on the part of human subjects. 
Sciences and the MacArthur Foundation Fellowship. UCSF is rated one of the top institutions in the United States where one can practice science, and its program in biopharmaceutical sciences ranks as one of the best nationwide.

\section{Definitions and Meanings}

The word 'meaning' has many uses, many of which are more evocative than precise. (Hacking, 1983: 75)

After only a few weeks with PMT, it became clear that the use of race was less a meaningladen activity than a practical tool to organize their study, and a way to drive hypotheses about how their research findings might eventually shed light on population disease risk and pharmacological susceptibility. Most of the variation that PMT scientists found was what they termed 'cosmopolitan', i.e. it existed in all racialized groups under study. Yet the rare protein-altering variants were largely found in specific groups and, in AfricanAmericans in particular. The team and their collaborators interpreted this to mean that their findings were in keeping with much evolutionary genetics. Most working in this area believe that genomes from African populations have the most variation as a result of the 'Out of Africa' event that, for thousands of years, separated those who remained on that continent from those who migrated to other regions of the world. For the team, this confirmed their belief that racial groups could, and should, be talked about as biologically distinct, for they were seeing some distinctions between the African-American samples and those labeled 'Caucasians'. But what exactly was the racial distinction that they were using to allocate individuals to these groups in the here and now? Several of PMT's own top researchers were of 'mixed-raced' origins, 'Filipino and Italian', 'South Asian and Czechoslovakian', 'Mexican and French-Canadian' and so on. In the formal interviews, when all of my questions about the definitions of transport, cellular phenotype, and pharmacological methods and measures of uptake had been answered, I posed the obvious question about the most basic of their scientific tools. I asked my informants to define race. The following is an excerpt of my conversation with Kathy Giacomini on the issue.

DF: One thing that I want to ask every scientist is how he or she defines race.

$K G$ : [laughs]

DF: And how you as a scientist explain the concept?

$K G$ : You know-probably I haven't given that as much thought as I should have. But my guess would be-I mean my feeling ... of race ... [pauses for 14 seconds] ... versus ethnicity? Or just race?

$D F$ : Just race.

$K G$ : [pauses for 2 seconds]

$D F$ : As you understand it.

$K G$ : My understanding of race is ... is ... and I don't even know what the broad definition of race ... what the acceptable definition of race is. But my understanding of race is that there are three major races-that there's a Caucasian race, that that is a race-as opposed to European, OK. And there's an, an, an African race. 
And, um, and there is an Asian race. That is my understanding of race, that those are racial groups. Now are you going to ask me what characterizes a race? Are you going to ask me those kinds of things [laughing shyly]?

DF: No. Just in terms of the science that you do, how do you understand it scientifically? Does your science give you a certain vantage to understand race in a particular way? $K G$ : Oh, OK, yes. So there, I think there are populations that have been geographically isolated and then formed-have their own, over the years, have their own variants, SNPS, things that they carry within their own population because they were isolated from other populations that allowed these specific isolated populations to have their own-[well] share a common genetic make-up, but have their own particular variants that they carry within that population. So yeah, I guess I do see race as sort of a genetic definition. I certainly saw it when I started re-sequencing these genes. You do see very population-specific variants along with a background of cosmopolitan variants.

I then asked about the significance of these rare variants within pharmacogenetics as a whole. Did such SNP differences, which may be found in some members of one group, but are not found in the majority of people from in that group, have special meaning because they are 'racially specific?'

DF: I know that you have discovered a lot of singletons, and those have been important in some of your publications ...

$K G$ : Yes.

DF: In the age of SNPs, and where everyone's interested in SNPs, meaning that genomic changes have to affect 1 percent of the population ...

$K G$ : Right, 1 percent or greater.

DF: So that's the threshold. So do your singletons get tossed out [as far as the larger scientific community is concerned], or when race comes in, and the change then becomes 'common', or more than 1 percent for that particular race or ethnicity does that matter? Let's say the change in question is 0.5 percent across the board or even less, but if you just look at one race it's larger. Does that sort of rescue these rare alleles in the age of SNPs where there is this 1 percent cut-off point? Do you feel that it's worth keeping these rare alleles, sometimes singletons, in the game even if they don't meet that SNP definition, across the board as 1 percent of the population?

$K G$ : So here-let me tell you I have a couple of minds on this. First of all, a rare SNP, and that must be an oxymoron [laughs], but a rare variant of some sort can teach us a lot. I am very attracted to rare variants. And I'm not exactly sure why I am. I think it's because you can learn a lot from a rare variant. Particularly if it's a rare variant that hasn't had a chance to be selected against. So it may be nonfunctional, it may exist in one population, so yes I like to-I don't want to say rescue-I like to keep the rare variants in mind. Secondly, I do exactly what you say. I think if it's important in a particular ethnic group, or any particular population, if it goes above 1 percent for that population, we should certainly consider that because it may have a particular effect in that population alone. So I feel very strongly that we should [do this]. But even, let's say that it doesn't go above 1 percent for a specific population, that it was just found one time, on one 
chromosome-in one African-American for example we have a SNP-I mean a mutation that was just found once, but it's non-functional and we know it because we tested it in the laboratory. Well, that's probably very important for that one individual and for his or her family. And secondly, it can tell us about mechanism and that's very important to me...

We have found in SOPHIE-you know when you re-sequence things, you find things - and we found stop codons, for example, in a couple of the genes. This means that those stop codons, especially if they are in the middle of the coding region, are going to give us a truncated protein, and it will be non-functional. They are almost always singletons. You don't find stop codons in big numbers. So I would love-we know who the individuals are because they're in SOPHIE, and I would like to study them because I could learn something about mechanism in humans in a person that has a non-functional allele. You know, I could learn something. So those are some of the studies that I would like to think about designing... .

And then we would learn about drug mechanism in a way that we could design better drugs for all different people. So I am thinking about pursuing rare variants, especially ones that are non-functional. But you're correct. If a rare variant is found at a certain frequency only in a certain population, I certainly wouldn't ignore it.

Later in the interview I asked her about debates in scientific circles on the validity of race based on clustering studies. This excerpt shows Giacomini's ethics, and her clear concern not to do harm by using race. It also shows her belief that science and truth will eventually settle these dilemmas.

DF: Do you have any feeling about these genetic studies that say that we shouldn't look at race and that we should just allow people to cluster into groups?

$K G$ : Oh. Those are interesting. So, I'm of two minds here. One mind I'm of is the-the idea that race can be used to hurt people in some way bothers me. And some way, deep down, I don't want anything I do to ever hurt a group. Now that would be-I don't know, that would be bad. So part of me feels that if you could cluster in some way it might be fine. You'd get rid of maybe having to hurt a group, by saying 'Oh you have this weird transporter'. I can't imagine how that could hurt, but let's say you find something like that. So, yes, clustering seems OK [hesitates] ... to me. But at the same time though, I feel like people do have racial groups and they're proud of it, and so they don't even mind knowing about their variants and all of that.... If it were me, I would just want to know what my genes are period. So clustering may help, and you read the debates, but I also don't see anything wrong with finding the variants in a particular ethnic group.

DF: You just have this background notion that things have been used to discriminate against a group perhaps?

$K G$ : Yes. You know it's happened and you just don't want it to happen. It concerns you, but at the same time you feel that the optimistic view is that we do get over that and that it ultimately will be OK.

The next excerpt comes from a postdoctoral researcher (PD) on PMT, a former graduate student of Giacomini, who is also her closest partner on the project in terms of thinking 
through problems and analyzing the data. The postdoc has also authored or co-authored several of PMT's more comprehensive scientific journal articles.

$D F$ : How would you define race?

$P D$ : That's a good question. I mean I-from my limited knowledge-and you know I'm still learning so much about population genetics and how variation differs between groups-but I do feel as though there are ethnic-specific SNPs. Because it seems as though people-when people do these large-scale genomic screens, they see these frequencies in the groups. One SNP will only pop up in one group, and another SNP will pop up only in another group. So I do think that there's some genetic basis for ethnicity or race. In terms of defining a given race based on SNPs or genetic variation, I don't think we know enough yet to do that. But from what I've seen, I do think that there are genetic differences, or more global genetic differences between-and maybe it's just sub-populations. I don't know-I don't really know what defines a race or an ethnicity, and I get confused between 'What is a race?' and 'What is an ethnicity?' So ...

DF: So you're going on what you've seen. You've seen SNPs appear in what have been defined as different groups?

PD: Yeah. That's what people report... I don't know because I don't know how they are defining their races and ethnicities, but I do think that it's not just chance. ...

DF: Before you got into SNP mapping, how would you have defined race?

$P D$ : I think before I got into all of this, I would have thought, 'Oh, where are your parents from?' And you know, my dad came from India. I actually grew up in a very mixed background. My dad grew up in India until he was 25, and my mom is part Czechoslovakian, so I'm of very mixed descent. So, if someone had two parents and they were second generation, and the parents came from China, I would say oh, they are Chinese. I mean that was my simple kind of definition of somebody's race or descent. But I think of it much differently now ...

DF: As a mixed person of Czechoslovakian, Indian ...

$P D$ : And everything else! [laughs]

DF: Do you feel that the racial categories that we use, for example in the United States, Black, White, Asian and Hispanic, etc. are too simplistic? Would you expand these if you could?

PD: It always—as a child it always bothered me. I hated it on tests-you know, when you took your SAT test, or when you apply for college, they ask you to check off this box: Are you Asian, Caucasian, African-American or Other? You know, and I didn't feel like putting Other. You know, because Other just seems like, 'Gosh, I don't belong to anything.' It kind of makes you feel-I just thought it was weird. I never liked the fact-no. I didn't like the fact that you had to define yourself as one race... So I guess it depends on the situation. I guess in social-type things, I don't even want to have to think about it, if that makes any sense?... So, I have two extremes: when I'm doing my genetic type of research, I want things very well defined, and in a social setting I don't even want to think about it. I don't know if that makes any sense? [laughs] 
This next excerpt is from PMT's primary technician (T) at the UCSF genetics core facility who is responsible for the actual genotyping of PMT's Coreill and now SOPHIE DNA for transporter genes.

DF: One thing I'm asking every scientist, and this comes out of the debates in Nature Genetics and other journals, is about the use of race in science and medicine. First, how would you define race?

T: Oh geez! Touchy subject. How would I define race? Um. [pauses for 9 seconds]. I think that-my preference would be to define race genetically. In such a way that there are certain groups of people that share genetic markers-a set of common genetic markers that is different from the set of genetic markers shared by a different group. One of the difficulties that you run into when you define race is that the species is able to have interrelationships, right? And how do you define race as a percentage of ancestry?... We can produce mixed-race children. So I don't know. I leave it up to the sociologists I guess to define race... [laughs]

DF: So the mixed-raced children would not fit your original definition of race based on genetic markers that are only found in one group, but not another?

T: Right.

DF: So then, scientifically, how do you keep race in the running? How do you think about race scientifically, so that you can define it as a scientific concept?

T: Um ... I try to avoid it! [laughs] ... So, one thing you learn about being a biologist is that you can make assumptions. You can make generalizations and they're not going to be true in every case. And, you know, that's what race is. It's a generalization. You look at a person, or you do a genetic profile, and you say this person has a genetic profile of a Caucasian, or this person has a genetic profile of an African-American, but for all you know that may not be the case, and so you can only judge race to a certain degree of confidence. Um, does that make sense?

The next excerpt comes from a postdoctoral fellow (PD) in the Burchard lab who had recently arrived in the US from South Asia. During the first three months of her stay, she quickly learned to use six statistical computational programs to sort DNA polymorphisms and sieve through them for heredity patterns. On most days, in this second lab, the researchers were interested in Puerto Rican and Mexican asthma genetics. Yet they were trying to understand asthma prevalence in these two groups, in part, through DNA markers found at disproportionate rates in select 'European', 'African', and 'Native American' populations. Through a process termed 'admixture', these latter groups were thought to 'comprise' the biological underpinnings of what these researchers called 'new world' Latino genetic difference. After a very short training period, this postdoc was soon presenting racialized results at lab meetings and debating which techniques and statistical measures should be used to corroborate their findings. She eventually first-authored two important papers wherein the lab reported their findings on race as it linked to various asthma SNPs in Puerto Ricans and Mexicans. In our interview, she is initially quite certain that race should be used as a practical tool for locating genes in bodies that may not possess the same percentages of ancestry from Europe, Native America and Africa. It becomes clear that she thinks of race somewhat like caste, which in her home country tracks with disease prevalence. Later in the interview, however, she sees race somewhat differently when she attempts to define it. 
In the end, she realizes that race, the lab's most basic technological tool for sorting human difference, requires more thought on her part.

DF: One of my research questions is how race is used in science... So my question to you is, how would you define race?

PD: [pauses for 7 seconds] ... I, I, I haven't thought about it-like in detail. There are a lot of definitions people use. But, but, after reading all of the [debates] in the literature-I'm like-the people who say that you shouldn't study race, and all of that, I'm against that. Maybe studying race can give you a lot, a lot of insight. So all these complex disorders [like asthma], why not compare different races with different prevalences of diseases and comparing them might give you some clue that they are different-at like, at say, at these chromosomal positions-why not study them, right, just compare? Do this practical thing, just compare and that can give you some clue that can narrow down your search for genes for asthma. Why not use it instead of making-uhm, like-well, I agree that we should be very careful when reporting all of these kinds of results, but, but then- not studying them? Not using the information that is there? Just seeing it-in India, different castes have different rates of diabetes, you are seeing it, why not use it, right?

DF: So, OK, you have caste in India, then within the United States [in your study] you have Hispanics, and you have divided them up into Mexicans and Puerto Ricans. So, you're saying that we shouldn't ignore race, but what is race?

$P D$ : Uhm, so [pauses for 6 seconds] ... so usually I think the race thing people use is [for] people who speak the same language and [have] the same social background, ... [hesitates] I think. But, then-then the thing is when you divide Mexicans and Puerto Ricans-Mexicans and Puerto Ricans have all the same-they speak the same language and they have almost the same social set-up, so they're the same, so-but then Mexicans and Puerto Ricans have very different, say asthma, they're very different, right? So.

DF: So, it couldn't just be language and social background.

$P D$ : Yeah.

$D F$ : So, if you were to make a definition, what would you say?

PD: Race... [pause for 18 seconds] ... What would I say? [laughs slightly] ... [pauses for 20 seconds] ... I think I need to think more about it, so.

One last excerpt from the lab head himself, Esteban Gonzáles Burchard, is instructive as it contrasts with those presented thus far. For Burchard, there is no pause. The moment of reflection in the other cases is here replaced with considerable certainty about the nature of human race typology. Burchard's conviction was common among my informants, but his was clarity rare. In this interview with Burchard, we see the many themes at stake in the debates brought together.

DF: How do you define race as a scientific concept?... That's [part of] the debate, right, that it is or it's not scientific?

EB: Well, race is usually thought of in US Census terms. There are five major racial categories: African, Caucasian, Native American, Pacific Islanders and Asians. If you don't like the term 'race,' you can use 'geographically defined groups', as they did 
in the Noah Rosenberg paper. But those are just surrogates for 'race'. If everyone comes from the African continent, that means that they're African, or thought of as black in today's terminology [pauses to think about this].

Although there are the vast majority of genetic similarities between populations, more similarities between groups, there is still a sizeable percentage of the genome, 7 percent, that separates population groups, African from Caucasian, Asians and so forth. And when you talk about the human genome, 7 percent is a substantial amount of the entire genome. So, to get back to your question ... a race is a defined set of individuals that have genetic similarity. However, race is not purely biological like gender is- $\mathrm{X}$ or $\mathrm{Y}$ chromosome. Race has a biological component that is largely shaped by environmental factors, sociologic factors, geographic factors-mountains, large oceans separating populations-and those aren't biologic in nature, but because they are affecting a biologic process, they are of biologic importance. That's where the debate is, really lies, there is a sociologic component to race, but it is not without a biologic basis.

For Burchard, the social sphere has a role to play, but the census office has race right when the small percentage of the genome that differentiates us by continental origin is the question. He sees the 'biologic' component of race as conditioned by geography and human history, but, for him, 'race' as 'a defined set of individuals that have genetic similarity' translates to five human types. These are surely affected by the 'sociologic' (unlike gender for him) but their biological 'similarity'," within the '7 percent', proves 'substantial'.

\section{Conclusion}

Pharmacogenetics is, by definition, concerned with human differences, with differential distribution of allelic frequencies, and considers these to have arisen over time from human beings' interaction with, and adaptation to, xenobiotics encountered in the form of plants, foods, toxins and the rest. It is not hard to imagine how such genomic diversity evolved, and why, as one of the researchers cited above puts it, 'ethnic-specific' SNPs 'pop up in one group, but not in others'. The intellectual leap that takes each researcher from this particular notion of specificity to the idea that race is the right conceptual tool to account for such differences is more difficult to explain. Recall that these are reputable scientists who are familiar with the debates and who still pursue their research with a certain conviction, full of good intentions.

With the completion of the draft of the human genome in the summer of 2000, many people were hopeful when leading scientists also announced that race had no genetic basis. Some imagined such statements would lead us into a new humanism in the twenty-first century. That same year British sociologist, and postcolonial theorist, Paul Gilroy could write:

[I] $\mathrm{t}$ is difficult to resist the conclusion that the biotechnological revolution demands a change in our understanding of 'race' ... and human specificity. In other words it asks that we reconceptualize our relationship to ourselves, our species, our nature and the idea of life. We need to ask, for example, whether there should be any place in this new paradigm of life for the idea of specifically racial differences. (2000: 20) 
The revolution continues, itself undergoing speciation within genomics. Certain ideas and ideals that the public projected onto the Human Genome Project, with which certain hopeful scientists ran, included 'post-anthropological' conceptions of humans (Gilroy, 2002: 15) as something other than 'racial' beings, which clustering studies might circumnavigate (Wilson et al., 2001).

Despite the range of possibilities for race thinking presented by the completion of the sequencing of the human genome, the deployment of race within genomic science has most recently become a platform on which minorities themselves have come to demand that their health be addressed by the genetic revolution. We can see this, for example, in actions from the Association of Black Cardiologists championing BiDil as the first racespecific heart-failure medication (Kahn, 2003: 475), and in the Howard University database project calling for 'African-American' genome research (Kaiser, 2003: 1485). Genetics, along with market notions of tailored medicine and (health) advocacy, has indeed entered us into a new 'humanism' in the United States, but it is one that needs-in fact, demands-that attention be paid to the materiality of human differences made visible by medical genetic technology in order to somehow 'equalize' life chances. Equality, despite genetic distinction, is its proclaimed goal. Inherently, this constellation of promised parity (largely reliant on difference) raises both the specter of new forms of biological racism and an ethical obligation to focus on those in our society who, as groups, are counted as the most ill (who are also, not so coincidentally, those who have historically been the objects of biological and other types of racism). Our current molecular-based humanism demands that both social and life scientists begin to define the parameters of race, and to seriously query its relationship to biology, culture, language, power and health. None of these categories can provide a complete account, none is reducible to the others.

More precisely tailored drug molecules may be in the pipeline, but we must pause to consider whether or not the molecularization of race-marking DNA as raced from the time it is extracted to the time that it appears in journal articles-is truly the best 'pathway' to attaining 'rational' and 'individualized' medicine. What kind of rationality is in question here? As Weber noted, different forms of rationality can underpin social actions. For this reason he made a distinction between rationality that was 'technocratic/pragmatic' versus 'affect-based', as well as rationality that was 'traditional' versus 'value-laden, when evaluating how humans determine 'certainty in understanding' (Weber, 1947/1964: 90). In the case of the use of race in pharmacogenetics, all four rationalities are in play. The accounts given by those who I interviewed show clearly that the technocratic/pragmatic rationality so central to the work of research operates within a value-laden, affect-based form of rationality. We can even find traces of traditional forms, as racial taxonomies here are undergirded by considerations other than science. Most of my interlocutors were unsure of the meanings of the race categories that they used, yet they continue to assert that there is a biological basis to them, which they will soon corroborate once they have done comparative studies in the human groups defined by them. That this system reaffirms itself remains unproblematic for many practitioners of this rational medicine.

A last lesson from Weber may be warranted in closing. One of the dangers of capitalism is that rationalization, paradoxically, often ceases to reflect on itself, and hence behaves in ways that undermines its goals. This is what Weber termed the irrationality of rationalization (1947: 92). In examining rationales to develop pharmacogenomics, which many hope 
will decrease health disparities, one cannot but wonder if genomics' new emphasis on human difference (and the processes of impersonal calculation of allelic frequency distributions that sustain it) will perhaps irrationally exacerbate social notions of difference and the inequalities that these have traditionally borne. Despite their good intentions, many scientists in the field of pharmacogenetics believe, and therefore communicate, that genetic difference sorts by race and, thus, that 'there is a genetic basis for race or ethnicity'. It thus follows that the rationalization of medicine is also proving to be a rationalization of race in the name of better potential health care. As such, it runs the risk of irrationalizing both.

\section{Acknowledgments}

The author would like to thank Troy Duster, Filippa Lentzos, Alondra Nelson, Rayna Rapp and Matt Wray for their helpful comments. This research was funded by a grant from the National Science Foundation, no. 0208100. The writing phase was supported by the Robert Wood Johnson Health and Society Scholars program.

\section{References}

Braun, L. (2002). Race, ethnicity, and health: Can genetics explain disparities? Perspectives in Biology and Medicine, 45, 159-174.

Bourdieu, P. (1977). Outline of a theory of practice. Cambridge: Cambridge University Press.

Burchard, E.G., Ziv, E., Coyle, N., Gomez, S.L., Tang, H., Karter, A.J. et al. (2003). The importance of race and ethnic background in biomedical research and clinical practice. New England Medical Journal, 348, 1170-1175.

Collins, F.S. (2004). What we do and don't know about 'race', 'ethnicity', genetics and health at the dawn of the genome era. Nature Genetics Supplement, 36, S13-S15.

Cooper, R.S., Kaufman, J.S., \& Ward, R. (2003). Race and genomics. New England Journal of Medicine, 348, 1166-1170.

Duster, T. (2001). The sociology of science and the revolution in molecular biology. In J.R. Blau (Ed.), The Blackwell companion to sociology, 213-226. Malden, MA: Blackwell.

Editorial (2000). Census, race and science. Nature Genetics, 24, 97-98.

Evans, W.E., \& Relling, M. (1999). Pharmacogenetics: Translating functional genomics into rational therapeutics. Science Magazine, 286, 487-491.

Fausto-Sterling, A. (2004). Refashioning race: DNA and the politics of health care. Differences, 15, 1-37.

Foster, M.W., \& Sharp, R.R. (2002) Race, ethnicity, and genomics: Social classifications as proxies of biological heterogeneity. Genome Research, 12, 844-850.

Fullwiley, D. (2007). The molecularization of race: Institutionalizing human difference in pharmacogenetics practice. Science as Culture, 16, 1-30.

Gilroy, P. (2000). Against race: Imagining political culture beyond the color line. Cambridge, MA: Harvard University Press.

Hacking, I. (1983). Representing and intervening: Introductory topics in the philosophy of natural science. Cambridge: Cambridge University Press.

Hacking, I. (1995). The looping effects of human kinds. In D. Sperber, D. Premack, \& A. Premack (Eds), Causal cognition: An interdisciplinary approach. Oxford: Oxford University Press.

Hacking, I. (2002). Historical ontology. Cambridge, MA: Harvard University Press.

Kahn, J. (2003). Getting the numbers right: Statistical mischief and racial profiling in heart failure research. Perspectives in Biology and Medicine, 46, 473-483.

Kahn, J. (forthcoming). Patenting race in a genomic age. In B. Koenig and S. Soo-Jin Lee (Eds), Revisiting race in a genomic age. Newark: Rutgers University Press.

Kaiser, J. (2003). African-American population biobank proposed. Science Magazine, 300, 1485.

Lee, J., \& Bean, F.D. (2004). America's changing color lines: Immigration, race/ethnicity, and multiracial identification. Annual Review of Sociology, 30, 221-242. 
Lee, S.S.J., Mountain, J., \& Koenig, B.A. (2001). The meanings of 'race' in the new genomics: Implications for health disparities research. Yale Journal of Health Policy and Ethics, 1, 33-75.

National Institute for General Medical Sciences (NIGMS) (2000). Medicines for You. URL (accessed May 2004): http://www.nigms.nih.gov/funding/meIoryou.html

Nature Genetics Editorial (2002). Census, race, and science. Nature Genetics, 24, 97-98.

Ossario, P., \& Duster, T. (2005). Race and genetics: Controversies in biomedical, behavioral, and forensic sciences. American Psychologist, 60, 115-128.

Pharmacogenetics Research Network (PGRN) (2002). Abstracts of Funded Supplements to the Pharmacogenetics Research Network for Health Disparities. URL (accessed May 2004): http://www.nigms.nih.gov/ pharmacogenetics/prnsupp_abstracts.html

Risch, N., Buchard, E.G., Ziv, E., \& Tang, H. (2002). Categorization of humans in biomedical research: Genes, race and disease. Genome Biology, 3, 1-12.

Weber, M. (1947/1964). The theory of social and economic organization. New York: The Free Press.

Wellner, A.S. (2003). Bridging the gap. Forecast, February, 2.

White House, Office of the Press Secretary (2000). Remarks by the President, Prime Minister Tony Blair of England, Dr Francis Collins, Director of the National Human Genome Research Institute, and Dr Craig Venter, President and Chief Scientific Officer, Celera Genomics Corporation, On the Completion of the First Survey of the Entire Human Genome Project. URL (accessed May 2004): http://clinton3.nara.gov/WH/EOP/OSTP/html/ 00628_2.html

Wilson, J.F., Weale, M.E., Smith, A.C., Gratrix, F., Fletcher, B., Thomas, M.G. et al. (2001). Population genetic structure of variable drug response. Nature Genetics, 29, 265-269. 